\title{
Leachate seepage from landfill: a source of groundwater mercury contamination in South Africa
}

\author{
V Nevondo', T Malehase', AP Daso' and OJ Okonkwo'* \\ 'Department of Environmental, Water and Earth Sciences, Tshwane University of Technology, Pretoria, 0001, South Africa
}

\begin{abstract}
Mercury has been used for many centuries in the production of consumer products such as thermometers, electrical switches, fluorescent light bulbs, batteries, biocides and pesticides, cosmetics and dental amalgam filling, among others. After use, these mercury-containing consumer products form part of the municipal solid waste (MSW). As a result of an unseparated solid waste collection system, mercury-containing wastes tend to end up in landfills where mercury and other pollutants can leach out of products into landfill leachates. The present study, therefore, was conducted with the aim of determining the total mercury (THg) concentrations in leachate and sediment samples collected from 4 selected landfill sites (3 sites in Gauteng Province - Soshanguve, Hatherly, Onderstepoort and 1 site in Limpopo Province - Thohoyandou). Groundwater samples were collected from the monitoring boreholes at the four selected landfill sites in the summer and winter periods. An acid digestion method was employed for sample preparation and this was followed by analysis using cold vapour atomic absorption spectrophotometry (CVAAS). The concentration range of total mercury in the Thohoyandou leachate, sediment and groundwater samples was $0.12-2.07 \mu \mathrm{g} / \mathrm{L}, 0.03-0.48 \mu \mathrm{g} / \mathrm{g}$ and $0.09-2.12 \mu \mathrm{g} / \mathrm{L}$, respectively. In Soshanguve, the concentration range of total mercury in leachate, sediment and groundwater samples was $0.10-1.20 \mu \mathrm{g} / \mathrm{L}, 0.04-0.62 \mu \mathrm{g} / \mathrm{g}$ and nd $-1.66 \mu \mathrm{g} / \mathrm{L}$ respectively, Hatherly concentration range was $0.42-1.31 \mu \mathrm{g} / \mathrm{L}$ and $0.06-0.78 \mu \mathrm{g} / \mathrm{g}$ in leachate and sediment, respectively and in Onderstepoort the concentration range was $0.12-2.41 \mu \mathrm{g} / \mathrm{L}, 0.03-0.50 \mu \mathrm{g} / \mathrm{g}$ and $0.05-2.44 \mu \mathrm{g} / \mathrm{L}$, in leachate, sediment and groundwater, respectively. The findings from this study suggest that there is a likelihood of groundwater pollution by mercury from landfill leachate seepage, particularly for landfills that are not lined with a geomembrane.
\end{abstract}

Keywords: mercury, municipal solid waste, leachate, sediment, groundwater

\section{INTRODUCTION}

The rapid rise in economic and population growth, and industrial development coupled with urbanization, has resulted in a continuous increase in the generation of municipal solid waste (MSW) in most countries including South Africa (Gwebu, 2003; Ayuba et al., 2013; Ramaiah et al., 2017; Naveen et al., 2017; Renou et al., 2008; DEA., 2012a). Factors such as the population of a country, lifestyle changes, food habits, improved standards of living, enhanced industrial and commercial activities, cultural traditions of the inhabitants, and climate may influence the composition and quantity of municipal solid waste generated in most countries (Singh et al., 2008). Municipal solid waste mainly comprises general and hazardous waste in the form of biodegradable waste, paper, plastic, glass, metal, textile and leather (Cheng and Hu, 2010; Slack et al., 2004, Machado et al., 2009). The disposal of municipal solid waste contributes to the emerging environmental pollution problem worldwide (Demirbas et al., 2016). Sanitary landfilling is known to be the simplest and cheapest primary method for disposal of municipal solid wastes where large quantities of leachate are produced (Jhamnani and Singh 2009; Longe and Balogun 2010; Kumar et al., 2016). According to the Department of Environmental Affairs (DEA, 2012), over $90 \%$ of all South Africa's waste is disposed of at landfill sites despite the implemented waste management strategies such as recycling. Furthermore, the National Waste Information Baseline Report (NWIBR) estimated that South Africa generated approximately 108 tons of waste in 2011 with 98 million tons being landfilled. Incidentally, some of these

\footnotetext{
To whom all correspondence should be addressed.

e-mail: OkonkwoOJ@tut.ac.za

Received 3 May 2018, accepted in revised form 8 March 2019.
}

waste materials may contain toxic metals which may eventually leach out of the disposed items, thus causing detrimental effects to the environment.

Mercury $(\mathrm{Hg})$ is an element which is considered to be a global toxic pollutant because it persists and bio-accumulates in the environment (USEPA, 1997; Pacyna et al., 2006; Feng and Qiu, 2008; Zhang et al., 2008). Mercury is also known to cause health problems such as tremor in facial muscles, eyelids and limbs, delusions, memory loss and neurocognitive disorder (Clarkson and Mangos, 2006). In foetuses, exposure to mercury inhibits mental and motor development, leading to poor intelligence (Ekino et al., 2007; Eto, 2000; Duruibe et al., 2007; Oliver-Verbel et al., 2008). The first health effects of mercury on human health were documented in the early 1950s and 1960s following a well-known incident of mercury poisoning which took place in Minamata, Japan, where fish contaminated with mercury were consumed by the local residents (Harada, 1995). Consequently, the Minamata Convention on Mercury was initiated by the United Nations through the United Nations Environment Programme (UNEP) (Malehase et al., 2016). Due to its unique characteristics, mercury has been used for many centuries in the production of consumer products such as thermometers, electrical switches, fluorescent light bulbs, batteries, biocides and pesticides, cosmetics, dental amalgam filling and others (Pacyna et al., 2003). After use, these mercury-containing products form part of the municipal solid waste (MSW) that is collected and disposed of into landfills where mercury and other pollutants could be leached into landfill leachates. Consequently, mercury may become an important constituent of the resulting leachate which is often characterized by high loads of dissolved organic matter, inorganic macro-components, metals and other xenobiotic organic compounds (Christensen et al., 1994 and Christensen et al., 2001). Usually, leachate accumulates at the bottom of 
the landfill and seeps into the collection ponds within the site. Sometimes, some of the leachate may percolate through the soil to contaminate the groundwater, particularly in an unlined landfill (Mor et al., 2006). Advection and diffusion are also transport processes responsible for contaminant mixing and movement of leachate into groundwater (De Soto et al., 2012).

Globally, a number of studies where infiltration of landfill leachate has been implicated as a potential source of groundwater pollution have been documented (Abu-Rukah and Al-Kofahi, 2001; Arneth et al., 1989; Christensen et al., 1998; Flyhammar, 1995; Looser et al., 1999; Rapti-Caputo and Vaccaro, 2006; Saarela, 2003). However, these studies barely listed mercury as part of the contaminants that pollute groundwater. In South Africa, the levels of mercury in different environmental media have been studied (Malehase et al., 2016; Williams et al., 2011 and Oosthuizen et al., 2010). However, there is limited information on the possible contamination of groundwater with mercury from landfill leachate, particularly in South Africa. Furthermore, South Africa is a water-scarce country (Blignaut and Van Heerden, 2009) and, as a result, many people tend to rely on borehole water as a source of drinking water. In these instances, there is a high possibility of groundwater contamination with mercury, particularly where the landfill site is not lined with geomembrane material. The present study, therefore, aims at determining the concentrations of total mercury in leachate from landfill sites as well as in the groundwater samples from monitoring wells within the investigated landfill sites.

\section{MATERIALS AND METHODS}

\section{Study area}

Gauteng Province is the most urbanized, industrialized and highly populated province in South Africa with the cities of Pretoria and Johannesburg being the two major cities located within the province. The city of Pretoria is located approx. y $50 \mathrm{~km}$ north of Johannesburg. The city has a humid subtropical climate with moderately warm days and lies within a series of valleys and hills, with the Magaliesberg mountain range within the northern part of the city, $1370 \mathrm{~m}$ amsl. The summer period is between October and April, while winter occurs between June and August. The average range of rainfall and temperature for summer and winter are: $3 \mathrm{~mm}$ of rainfall in July and $154 \mathrm{~mm}$ of rainfall in January, and $3^{\circ} \mathrm{C}-19^{\circ} \mathrm{C}$ in July and $16^{\circ} \mathrm{C}-27^{\circ} \mathrm{C}$ in January, with most of the rain occurring in the summer months.

Limpopo is considered to be a developing province, and is located in the most northerly part of South Africa with Polokwane as its administrative capital. Thohoyandou, however, is one of the small towns located within the province, in the far northern part of Limpopo in the Venda region, and is mostly surrounded by rural communities. It falls within the tropical belt of South Africa. Thohoyandou receives rainfall of about $752 \mathrm{~mm}$ per year and the peak of precipitation usually occurs during the mid-summer (January) period. The average range of rainfall and temperature in summer and winter is between $4 \mathrm{~mm}$ and $22^{\circ} \mathrm{C}$ in July and $154 \mathrm{~mm}$ and $30.3^{\circ} \mathrm{C}$ in January, respectively. Figure 1 shows the location of the selected landfill sites (Soshanguve, Hatherly, Onderstepoort and Thohoyandou) within Gauteng Province (top left) and Limpopo Province (top right). Samples were collected from July to August 2016 (winter) and in January 2017 (summer).

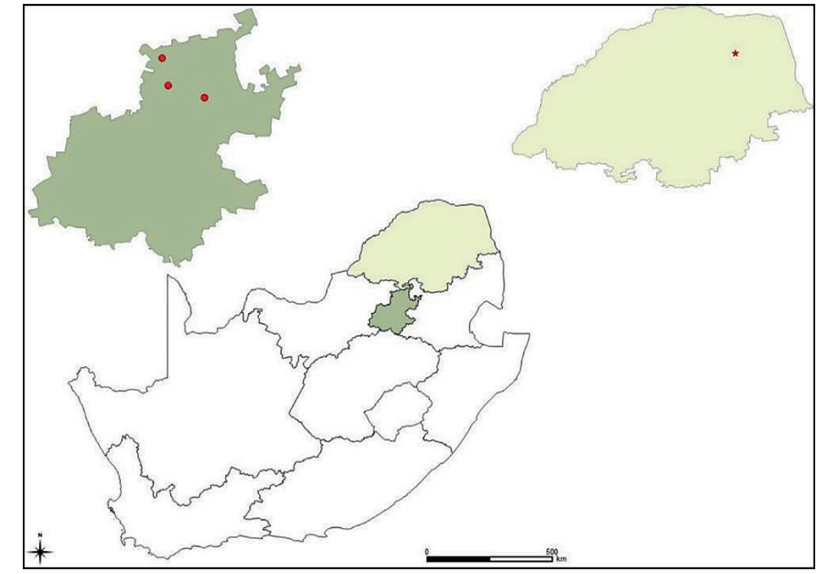

Figure 1

Location of the selected landfall sites within (top left insert) Gauteng Province and Limpopo Province (top right insert)

\section{Materials and chemical reagents}

All glassware used was thoroughly washed with liquid detergent and subsequently soaked overnight in $10 \%$ nitric acid, rinsed 3 times with de-ionised water and dried in an oven at $\pm 95^{\circ} \mathrm{C}$. All reagents used during the experiments were supplied by Sigma-Aldrich (Germany), and were certified as mercury free. Throughout the experiments, acids such as hydrochloric acid $37 \%$, nitric acid $70 \%$, and sulphuric acid $95-98 \%$ were used for sample digestion. Potassium permanganate $\geq 99 \%$, low in $\mathrm{Hg}$, was used to oxidize the mercury. Potassium persulphate $\geq 99 \%$, sodium chloride $\geq 99 \%$ and hydroxylamine sulphate $99 \%$ were used to further the sample digestion process. To reduce mercury to elemental mercury during analysis, aqueous tin chloride dihydrate prepared from tin (ll) chloride dihydrate was used. Ultra-pure water was prepared in the laboratory using an SG Series Compact apparatus, purchased from Evoqua water technologies (United Kingdom), and was used throughout the experiment. Standard solutions for AAS measurements supplied by FLUKA Analytical (Switzerland) and MERCK (Germany) were used for instrument calibration.

\section{Sample collection}

Table 1 shows the detailed description and general information for the four selected landfill sites. Leachate, sediment and groundwater samples were collected in triplicate from the four selected sites (Soshanguve, Hatherly, Onderstepoort and Thohoyandou) into thoroughly acid-washed Teflon plastic

\section{TABLE 1}

Detailed description and general information on selected landfill sites

\begin{tabular}{|l|c|c|c|}
\hline Site name & $\begin{array}{c}\text { Landfill age } \\
\text { (years) }\end{array}$ & $\begin{array}{c}\text { Type of } \\
\text { geomembrane } \\
\text { liner }\end{array}$ & $\begin{array}{c}\text { Size } \\
\left(\mathbf{k m}^{2}\right)^{*}\end{array}$ \\
\hline Soshanguve & 18 & No liner & 0.392 \\
\hline Hatherly & 15 & No liner & 0.960 \\
\hline Onderstepoort & 16 & No liner & 0.518 \\
\hline Thohoyandou & 15 & No liner & \\
\hline
\end{tabular}

*Source: (Sibiya et al., 2017) Adapted from general waste minimization plan for Gauteng 
containers. A grab sampling method was used to collect leachate samples from the leachate ponds and sediment samples were collected by scooping at $0-5 \mathrm{~cm}$ below the surface of the leachate pool at the same point where the leachate samples were collected.

Groundwater samples were collected from the monitoring boreholes at $25 \mathrm{~m}$ depth within the selected landfill sites. The samples were labelled and covered immediately after sample collection, kept in cooler bags (ice chests) and transported to the laboratory where they were kept at $-4^{\circ} \mathrm{C}$ in a refrigerator until further analysis. The landfill sites were selected considering the fact that Gauteng Province is the most developed, highly populated and industrialized province in South Africa, while Limpopo Province is a developing area and mostly comprised of rural communities. Other parameters, such as age of the landfill, size, waste type and lining of landfill were also considered during selection of the landfill sites. The composition of waste that was collected from the different landfills differs depending on the income level of people and the geographic location of the municipality (DEA, 2012). The waste residues in the Pretoria landfills comprised 32\% greens, $46 \%$ household, $14 \%$ builder's rubble and $8 \%$ industrial wastes (DEA, 2012). According to Ogola et al. (2011), the average composition of household waste generated per week in Thohoyandou includes $6 \%$ garden, $18 \%$ plastic, $20 \%$ paper, $34 \%$ food waste and $11 \%$ glass.

\section{Sample preparation}

Sediment samples were air-dried at room temperature for a week and homogenized prior to extraction. Leachate and groundwater samples from the selected landfill sites were unfiltered. For the determination of total mercury in the leachate and groundwater samples, the acid digestion method procedures as outlined in USEPA Method 245.1 and USEPA Method 7471B (O'Dell et al., 1994; US EPA, 2007) were employed, respectively. About $1 \mathrm{~g}$ of homogenized sediment sample was weighed and transferred into a $250 \mathrm{~mL}$ sample bottle. Working under a fume hood and treating each sample individually, $10 \mathrm{~mL}$ of ultra-pure water was added followed by the addition of aqua regia 3:1. The sample bottles were then closed tightly to avoid loss of mercury vapour and heated in a water-bath for $2 \mathrm{~min}$ at $95 \pm 5^{\circ} \mathrm{C}$. After allowing the mixture to cool down, $50 \mathrm{~mL}$ of ultra-pure water was added, followed by the addition of freshly prepared potassium permanganate solution. In order to allow complete oxidation of the samples, the sample was allowed to stand for $15 \mathrm{~min}$, and it was further heated for $30 \mathrm{~min}$. After cooling, $6 \mathrm{~mL}$ of sodium-chloride hydroxylamine hydrochloride was added to remove excess potassium permanganate and the samples were filled to the mark, $250 \mathrm{~mL}$, and analysed. For leachate and groundwater samples; $100 \mathrm{~mL}$ of the sample was used, and the procedure as outlined above was carried out with the addition of $8 \mathrm{~mL}$ of potassium persulphate and the samples were heated for $3 \mathrm{~h}$ at $\pm 95^{\circ} \mathrm{C}$.

\section{Instrumental analysis}

For the analysis of mercury in the leachate, sediment and groundwater samples, $6 \mathrm{~mL}$ of aqueous tin chloride dihydrate was added to the samples to reduce the mercury to elemental mercury. The samples were analysed using cold vapour atomic absorption spectroscopy (CVAAS). The mercury vapour unit (MVU-A1) system was mounted on the atomic absorption spectrometer, Shimadzu AA-7000 (Japan).

\section{Quality assurance}

For method validation, certified reference material for mercury in stream sediment, CRM NCS DC 73312-73312 containing $0.072 \pm 0.009 \mu \mathrm{g} \mathrm{Hg} / \mathrm{g}$ manufactured by the China National Analysis Centre for Iron and steel (Beijing China), purchased from Industrial Analytical (Pty), South Africa, was used. An average recovery of $94 \%$ was obtained. Adequate care was taken to avoid loss of mercury during sample digestion. To avoid carryover during analysis, ultra-pure water and reagent blanks were analysed in between sample analyses.

\section{Data analysis}

All samples were prepared and analysed in triplicate and afterwards the mean and standard deviation were calculated. Statistical analysis was performed using Microsoft Excel 2016.

\section{RESULTS}

Table 2 shows the mean concentrations of total mercury (THg) in the leachate, sediment and groundwater samples from the four selected landfill sites (Thohoyandou, Soshanguve, Hatherly and Onderstepoort) during winter and summer. The mean concentrations and standard deviations presented are the results of triplicate extraction and analysis of each sample. The concentration range of total mercury in the Thohoyandou leachate, sediment and groundwater samples were $0.12-2.07$ $\mu \mathrm{g} / \mathrm{L}, 0.03-0.48 \mu \mathrm{g} / \mathrm{g}$ and $0.09-2.12 \mu \mathrm{g} / \mathrm{L}$, respectively, and in Soshanguve, Hatherly and Onderstepoort the concentration ranged from $0.10-1.20 \mu \mathrm{g} / \mathrm{L}, 0.04-0.62 \mu \mathrm{g} / \mathrm{g}$ and $\mathrm{nd}-1.66 \mu \mathrm{g} / \mathrm{L}$, $0.42-1.31 \mu \mathrm{g} / \mathrm{L}$ and $0.06-0.78 \mu \mathrm{g} / \mathrm{g}$ and $0.12-2.41 \mu \mathrm{g} / \mathrm{L}$, and $0.03-0.50 \mu \mathrm{g} / \mathrm{g}$ and $0.05-2.44 \mu \mathrm{g} / \mathrm{L}$ (groundwater samples were not accessible in Hatherly landfill site), respectively.

\section{DISCUSSION}

\section{Total mercury concentrations in leachate, sediment and groundwater samples}

The mean concentrations of total mercury obtained in leachate, sediment and groundwater samples were higher

TABLE 2

Mean concentrations of total mercury in leachate, sediment and groundwater \pm SD (standard deviation)

\begin{tabular}{|l|c|c|c|c|c|c|}
\hline Landfill ID & \multicolumn{2}{|c|}{ Leachate $(\mu \mathrm{g} / \mathrm{L})$} & \multicolumn{2}{c|}{ Sediment $(\mu \mathrm{g} / \mathbf{g})$} & \multicolumn{2}{c|}{ Groundwater $(\mu \mathrm{g} / \mathrm{L})$} \\
\hline & Winter & Summer & Winter & Summer & Winter & Summer \\
\hline Thohoyandou & $2.07 \pm 0.28$ & $0.12 \pm 0.02$ & $0.48 \pm 0.02$ & $0.03 \pm 0.01$ & $2.12 \pm 0.28$ & $0.09 \pm 0.01$ \\
\hline Soshanguve & $1.20 \pm 0.27$ & $0.10 \pm 0.01$ & $0.62 \pm 0.61$ & $0.04 \pm 0.01$ & $1.66 \pm 1.18$ & $\mathrm{nd}$ \\
\hline Hatherly & $1.31 \pm 0.51$ & $0.42 \pm 0.01$ & $0.78 \pm 0.53$ & $0.06 \pm 0.02$ & $\mathrm{NA}$ & $\mathrm{NA}$ \\
\hline Onderstepoort & $2.41 \pm 0.35$ & $0.12 \pm 0.01$ & $0.50 \pm 0.18$ & $0.03 \pm 0.01$ & $2.44 \pm 0.47$ & $0.05 \pm 0.01$ \\
\hline
\end{tabular}

nd: not detected; NA-not analysed (groundwater samples were not accessible at the Hatherly landfill site). 
in winter than in summer. Several factors, including the age of the landfill, (Kjeldsen et al., 2002), the composition of the waste materials disposed into the landfill, and the prevailing climatic conditions of a particular area, are known to influence the composition and the chemistry of landfill leachate. Lindberg et al. (2001) stated that chemical and biological processes which normally take place in the landfilled waste layers can lead to the formation of inorganic and organic mercury. As a result, mercury emission from landfills occurs in various ways which include via landfill gas (LFG), and as part of the air or surface exchange across the land cover (Lindberg and Price, 1999). In this study, the measured concentrations of the total mercury in the leachate, sediment and groundwater samples in winter and summer are likely to have been affected by any of these factors. For instance, the intensity of precipitation is known to have a strong influence on leachate composition because rainwater infiltration into the landfill leachate can dilute chemical components contained in the landfill leachate (Vadillo et al., 1999). In the landfill sites investigated in both Gauteng and Limpopo Provinces, winter and summer seasons are characterized by low and high precipitation, respectively. This may explain the higher and lower concentrations of total mercury obtained during winter and summer in the leachate, sediment and groundwater samples.

Furthermore, the activities of waste scavengers were noticeable at all of the sampling sites, where they often undertake on-site waste sorting for recycling purposes. It is, therefore, possible that the low concentrations of total mercury determined in the leachate, sediment and groundwater samples from these sites may have been influenced by these practices. The Onderstepoort landfill site exhibited the highest mean concentration of total mercury, $2.41 \mu \mathrm{g} / \mathrm{L}$, in the leachate samples during winter. This suggests that more mercury-bearing waste may have been dumped into this site compared to the Thohoyandou, Soshanguve and Hatherly landfill sites. Although the Thohoyandou landfill site is situated in a developing province (Limpopo), and is mostly surrounded by rural communities, in winter much higher concentrations of total mercury were detected in the leachate $(2.07 \mu \mathrm{g} / \mathrm{L})$ and groundwater $(2.12 \mu \mathrm{g} / \mathrm{L})$ samples from Thohoyandou compared to those from the Soshanguve and Hatherly landfill sites, which are situated in a highly populated and industrialized part of the country (Gauteng Province). The observed concentration profiles in the investigated matrixes may reflect the consumption or usage patterns of mercury-containing products in these areas. Additionally, the observed pattern may be an indication of the ratio of waste items containing mercury to the overall waste materials disposed of into a particular landfill. It is, therefore, expected that landfills situated in areas with low population densities may contain high levels of mercury and other contaminants because of the relatively lower quantities of overall waste materials being received. Furthermore, the Limpopo Province is richly endowed with geothermal springs which are natural sources of mercury. In a study conducted by Olivier et al. (2011), the concentrations of total mercury determined from Siloam and Tshipise springs were 0.53 and $0.33 \mu \mathrm{g} / \mathrm{L}$, respectively. The natural occurrence of mercury in groundwater is another important factor that needs to be considered, which may have contributed to the relatively higher concentrations of total mercury detected in the groundwater samples from the Thohoyandou landfill site.
The concentrations of total mercury in sediment samples obtained in winter were low compared to summer samples. According to Barringer and Szabo (2006), the sorption of mercury to iron hydroxides in soils is its major mechanism for attenuation but the presence of sulphide can reduce dissolved iron(II) hydroxides, thereby facilitating the release of the sorbed mercury thus leading to groundwater contamination. This might have influenced the leaching of mercury from sediment into groundwater, thereby polluting groundwater. The mean concentrations of total mercury in the groundwater samples in Thohoyandou, Soshanguve and Onderstepoort landfill sites during winter exceeded the WHO, NL, USEPA and SA maximum limits for mercury in drinking water, of $1.00 \mu \mathrm{g} / \mathrm{L}$ and $2.00 \mu \mathrm{g} / \mathrm{L}$, respectively (Table 3 ). Mercury in all its forms is toxic to human health. Health problems such as tremors, delusions, memory loss and neurocognitive disorder manifest in exposed individuals (Clarkson and Mangos, 2006). People living in the surrounding areas of Thohoyandou, Soshanguve and Onderstepoort landfill sites may be susceptible to the toxic effect of mercury through the consumption of contaminated water.

\section{The effect of pH on mercury}

The $\mathrm{pH}$ of landfill leachate is one of the factors that can influence the toxicity, bioavailability and mobility of mercury in landfill leachate. The $\mathrm{pH}$ values that were determined in leachate samples from Thohoyandou, Soshanguve, Hatherley and Onderstepoort landfill sites during winter were 7.8, 8.3, 8.4 and 8.7 , respectively, and 7.9, 8.4, 6.7 and 7.2 during the summer season, respectively. Higher leachate $\mathrm{pH}$ normally increases the concentration of negatively charged hydroxyl ions $\left(\mathrm{OH}^{-}\right)$, which might attract and retain divalent mercury (Xu et al., 2014). However, low leachate $\mathrm{pH}$ is characterised by high positively charged hydrogen $\left(\mathrm{H}^{+}\right)$ions which play a direct role in several reactions. According to Mahapatra et al. (2011), dissolved material in landfill leachate can shift the $\mathrm{pH}$ of neutral water either to the acidic or the alkaline side. At a $\mathrm{pH}$ that is greater than 7 , a greater load of dissolved substances is expected to occur in leachate, including metals. The alkaline nature of landfill leachate is an indicator of the mature stage of the landfill site (Jorstad et al., 2004). The alkaline $\mathrm{pH}$ determined in Thohoyandou, Soshanguve, Hatherley and Onderstepoort leachate samples may have influenced the determined concentrations of total mercury in the present study.

\section{TABLE 3}

Maximum limit concentrations of mercury in drinking water compared to concentrations obtained in the present study

\begin{tabular}{|l|c|l|l|l|}
\hline Organisation & $\begin{array}{c}\text { Maximum } \\
\text { limit } \\
\text { concentrations }\end{array}$ & Unit & \multicolumn{2}{|c|}{ Present Study $(\mu \mathrm{g} / \mathrm{L})$} \\
\hline & & & Winter & Summer \\
\hline WHO & $1^{*}$ & $\mu \mathrm{g} / \mathrm{L}$ & $2.12 \pm 0.28$ & $0.09 \pm 0.01$ \\
\hline USEPA & 2 & $\mu \mathrm{g} / \mathrm{L}$ & $1.66 \pm 1.18$ & $\mathrm{nd}$ \\
\hline $\mathrm{SA}$ & $1^{*}$ & $\mu \mathrm{g} / \mathrm{L}$ & $2.44 \pm 0.47$ & $0.05 \pm 0.01$ \\
\hline
\end{tabular}

*Source: Adapted from SA drinking water standard under the microscope. Data from World

Health Organisation, European Union, Netherlands, United State Environmental Protection Agency and South Africa (Mamba et al., 2008) 


\section{Comparison with other studies}

The concentrations of total mercury in the leachate, sediment and groundwater samples obtained in the present study were compared to concentrations obtained in other studies (Table 4). The concentrations of total mercury in the leachate samples obtained in the present study were in the same range as those reported by Schoeman et al, (2003), which ranged from $0.2-0.3 \mu \mathrm{g} / \mathrm{L}$. It is possible that factors similar to those reported in the present study may have influenced the measured mercury levels in the study. In another study, conducted by Tshibalo (2017), the concentration of total mercury in the leachate samples from the Onderstepoort landfill was $15.0 \mu \mathrm{g} / \mathrm{L}$, which is significantly higher than those found in the present study. This can be attributed to the different sampling points for leachate samples for both studies. Other studies conducted in China by Li et al. (2005) and Tang et al. (2003) gave concentrations of total mercury in leachate samples of up to $0.08 \mu \mathrm{g} / \mathrm{L}$ and $0.1-1.016 \mu \mathrm{g} / \mathrm{L}$, respectively. Concentrations of total mercury in leachate from the China studies were within the same range as the concentrations determined in the present study. In the USA, Aucott (2006) reported a concentration of total mercury in leachate of $7.15 \mu \mathrm{g} / \mathrm{L}$. This is higher compared to the concentrations determined in the current study.

According to USEPA, about $54 \%$ of municipal solid waste in the USA was landfilled (EPA, 2010a). Considering that the USA is a more developed country, landfills are likely to be constructed with geomembrane liners and with a good leachate drainage system, which may yield a leachate with high mercury concentrations in the drainage system to be treated accordingly. This may explain the higher concentration of total mercury determined in the USA study compared to the current study. Furthermore, the occurrence of mercury-containing products may be higher

\section{TABLE 4}

Mean concentrations of total mercury in other studies compared to the present study

\begin{tabular}{|l|c|l|}
\hline \multicolumn{3}{|c|}{ compared to the present study } \\
\hline Matrixes & THg concentrations & References \\
\hline Leachate & $0.20-0.30 \mu \mathrm{g} / \mathrm{L}$ & Schoeman et al., 2003 \\
\hline Leachate & $15.0 \mu \mathrm{g} / \mathrm{L}$ & Tshibalo, 2017 \\
\hline Leachate & $0.08 \mu \mathrm{g} / \mathrm{L}$ & Li et al., 2005 \\
\hline Leachate & $7.15-1.02 \mu \mathrm{g} / \mathrm{L}$ & Li et al., 2005 \\
\hline Leachate & $1.70-8.30 \mu \mathrm{g} / \mathrm{L}$ & Esakku et al., 2003 \\
\hline Leachate & $0.01-0.03 \mu \mathrm{g} / \mathrm{L}$ & Øygard et al., 2004 \\
\hline Leachate & $\mathbf{1 . 2 0}-\mathbf{2 . 4 1} \boldsymbol{\mu g} / \mathrm{L}$ & Present study, winter \\
\hline Leachate & $\mathbf{0 . 1 0 - 0 . 4 2 ~} \boldsymbol{\mu g} / \mathrm{L}$ & Present study, summer \\
\hline Sediment & $0.29-0.76 \mu \mathrm{g} / \mathrm{g}$ & Machado et al., 2002 \\
\hline Sediment & $0.19-6.53 \mu \mathrm{g} / \mathrm{g}$ & Cheng and Hu, 2011 \\
\hline Sediment & $314 \mu \mathrm{g} / \mathrm{g}$ & Tshibalo, 2017 \\
\hline Sediment & $\mathbf{0 . 4 8 - 0 . 7 8} \boldsymbol{\mu g} / \mathbf{g}$ & Present study, winter \\
\hline Sediment & $\mathbf{0 . 0 0 - 0 . 0 6} \boldsymbol{\mu g} / \mathbf{g}$ & Present study, summer \\
\hline Groundwater & $1.00-32.0 \mu \mathrm{g} / \mathrm{L}$ & Samadder et al., 2017 \\
\hline Groundwater & $2.00-5.00 \mu \mathrm{g} / \mathrm{L}$ & Tshibalo, 2017 \\
\hline Groundwater & $\mathbf{1 . 0 6}-\mathbf{2 . 4 4} \boldsymbol{\mu g} / \mathrm{L}$ & Present study, winter \\
\hline Groundwater & $\mathbf{n d - 0 . 0 9} \boldsymbol{\mu g} / \mathrm{L}$ & Present study, summer \\
\hline
\end{tabular}

in USA landfill sites compared to South Africa due to high industrialisation in the United States compared to South Africa. According to Esakku et al. (2003), the concentrations of total mercury in 7 leachate samples from selected landfill sites in India ranged from $1.70-8.30 \mu \mathrm{g} / \mathrm{L}$. Only two of the samples from the study had higher concentrations of total mercury than those from the present study. The solid waste management practices in India are mostly based on open dumping with poorly constructed drainage systems, if any. As a result, the leachate generated in the landfills from India may be of low quality compared to the landfills that are constructed with drainage systems. Such factors might have influenced the determined concentrations in the present study since the landfills in the present study are mainly open dumping. In western Norway, Øygard et al. (2004) determined the concentrations of total mercury from 4 landfill site leachate samples, which ranged from 0.01-0.03 $\mu \mathrm{g} / \mathrm{L}$. The occurrence of mercury-containing products in western Norway landfills may be lower and thus the reported low concentrations. The concentrations of total mercury in landfill sediment samples have been determined by other researchers as well. Studies conducted in a Brazil landfill gave concentrations of total mercury in sediment samples of $0.76 \mu \mathrm{g} / \mathrm{g}, 0.29 \mu \mathrm{g} / \mathrm{g}$ and $0.36 \mu \mathrm{g} / \mathrm{g}$ (Machado et al., 2002). In another study conducted in China, Cheng and $\mathrm{Hu}$, (2011) reported mercury concentrations of $0.19-6.53 \mu \mathrm{g} / \mathrm{g}$ in landfill sediment samples and in South Africa, Tshibalo (2017) reported $314 \mu \mathrm{g} / \mathrm{g}$ concentration of total mercury in sediment samples from the Onderstepoort landfill site. The concentrations obtained by these three researchers were higher compared to the concentrations obtained in the current study. Samadder et al. (2017) reported the levels of total mercury from 15 landfill borehole water samples and the measured concentrations ranged from $1.00-32.0 \mu \mathrm{g} / \mathrm{L}$, which are more than an order of magnitude higher than those reported in the present study. The high concentrations of total mercury obtained in Samadder's study can be attributed to the high population density and possibly socio-cultural practices in India, which may have resulted in the higher generation of mercury-containing wastes. Tshibalo (2017) reported a total mercury concentration of $2.00-5.00 \mu \mathrm{g} / \mathrm{L}$ in two borehole water samples from the Onderstepoort landfill site, which may be attributed to different sampling points and different seasons of sampling.

\section{CONCLUSIONS}

The present study shows the occurrence and concentrations of total mercury in landfill leachate, sediment and groundwater samples from selected landfill sites in winter and summer seasons. The concentrations of total mercury were notably higher in winter compared to summer concentrations in all analysed samples, possibly due to the dilution effects caused by the high precipitation in summer. It can be concluded that landfill leachate is capable of contaminating groundwater, especially where the landfills are not lined with a geomembrane material. Though the Thohoyandou landfill site is located in a developing province, the measured concentrations of total mercury were relatively higher compared to the concentrations determined at landfills situated within the Gauteng Province. Considering the fact that the measured concentrations of total mercury in groundwater samples exceeded the specified maximum guideline limit established by most regulatory agencies for drinking water during winter, it is likely that people living in the 
surrounding areas of the Thohoyandou landfill site, in particular, and who depend on groundwater for their livelihood, may be prone to the deleterious effects of mercury.

\section{ACKNOWLEDGEMENTS}

The authors are very grateful to the Tshwane University of Technology (TUT) and the National Research Foundation (NRF) for the funds provided for this research.

\section{REFERENCES}

ABU-RUKAH Y and AL-KOFAHI O (2001) The assessment of the effect of landfill leachate on ground-water quality-a case study El-Akader landfill site-north Jordan. J. Arid Environ. 49 615-630. https://doi.org/10.1006/jare.2001.0796

ARNET JD, MILDE G, KERNDORFF H and SCHLEYER R (1989) Waste deposit influences on groundwater quality as a tool for waste type and site selection for final storage quality. In: Baccini $\mathrm{P}$ (ed) The Landfill. Lecture Notes in Earth Sciences, vol 20. Springer, Berlin, Heidelberg. https://doi.org/10.1007/BFb0011276

AUCOTT M (2006) The fate of heavy metals in landfills: A review, New Jersey Department of Environmental Protection, New Jersey.

AYUBA KA, MANAF LA, SABRINA AH and AZMIN SWN (2013) Current status of municipal solid waste management practise in FCT Abuja. Res. J. Environ. Earth. Sci. 5 295-304.

BARRINGER JL and SZABO Z (2006) Overview of investigations into mercury in ground water, soils, and septage, New Jersey Coastal Plain. Water. Air. Soil Pollut. 175 193-221.

BLIGNAUT J and VAN HEERDEN J (2009) The impact of water scarcity on economic development initiatives. Water $S A$ 35 415-420.

CHENG H and HU Y (2010) Municipal solid waste (MSW) as a renewable source of energy: Current and future practices in China. Bioresour. Technol. 101 3816-3824. https://doi.org/10.1016/j. biortech.2010.01.040

CHENG H and HU Y (2011) Mercury in municipal solid waste in China and its control: a review. Environ. Sci. Technol. 46 593-605.

CHRISTENSEN TH, KJELDSEN P, BJERG PL, JENSEN DL, CHRISTENSEN JB, BAUN A, ALBRECHTSEN HJ and HERON G (2001) Biogeochemistry of landfill leachate plumes. Appl. Geochem. 16. 659-718. https://doi.org/10.1016/S0883-2927(00)00082-2

CHRISTENSEN JB, JENSEN DL, GRØN C, FILIP Z and CHRISTENSEN TH (1998) Characterization of the dissolved organic carbon in landfill leachate-polluted groundwater. Water. Res. 32 125-135. https://doi.org/10.1016/S0043-1354(97)00202-9

CHRISTENSEN TH, KJELDSEN P, ALBRECHTSEN HJR, HERON G, NIELSEN PH, BJERG PL and HOLM PE (1994) Attenuation of landfill leachate pollutants in aquifers. Crit. Rev. Environ. Sci. Technol. 24 119-202.

CLARKSON TW and MAGOS L (2006) The toxicology of mercury and its chemical compounds. Crit. Rev. Toxicol. 36 609-662. https://doi org/10.1080/10408440600845619

DEA (Department of Environmental Affairs, South Africa) (2012) National waste Information Baseline, 1-17. http://sawic. environment.gov.za/documents/1880.pdf.

DE SOTO IS, RUIZ AI, AYORA C, GARCI R, REGADIO $M$ and CUEVAS J (2012) Diffusion of landfill leachate through compacted natural clays containing small amounts of carbonates and sulfates. Appl. Geochem. 27 1202-1213. https://doi.org/10.1016/j. apgeochem.2012.02.032

DEMIRBAS A, ALAMOUDı RH, AHMAD W and SHE1KH MH (2016) Optimization of municipal solid waste (MSW) disposal in Saudi Arabia. Energ. Sources Part A. 38 1929-1937. https://doi.org/1 $0.1080 / 15567036.2015 .1034385$

DURUIBE J, OGWUEGBU M and EGWURUGWU J (2007) Heavy metal pollution and human biotoxic effects. Int. J. Phys. Sci. 2 112-118.

EKINO S, SUSA M, NINOMIYA T, IMAMURA K and KITAMURA $\mathrm{T}$ (2007) Minamata disease revisited: an update on the acute and chronic manifestations of methyl mercury poisoning. J. Neurol. Sci. 262 131-144. https://doi.org/10.1016/j.jns.2007.06.036
ESAKKU S, PALANIVELU K and JOSEPH K (2003) Assessment of heavy metals in a municipal solid waste dumpsite. Paper presented at Workshop on Sustainable Landfill Management, 3-5 December 2003, Chennai, India. 139-145.

ETO K (2000) Minamata disease. Neuropathology 20 14-19.

FENG X and QIU G (2008) Mercury pollution in Guizhou, Southwestern China-an overview. Sci. Total Environ. 400 227-237. https://doi.org/10.1016/j.scitotenv.2008.05.040

FLYHAMMAR P (1995) Leachate quality and environmental effects at active Swedish municipal landfill. Regulations, environmental impact and aftercare. Proceedings Sardinia 1995. 549-557.

GWEBU TD (2003) Population, development, and waste management in Botswana: Conceptual and policy implications for climate change. Environ. Manage. 31 0348-0354. https://doi.org/10.1007/ s00267-002-2883-4

HARADA M (1995) Minamata disease: methylmercury poisoning in Japan caused by environmental pollution. Crit. Rev. Toxicol. 25 1-24. https://doi.org/10.3109/10408449509089885

JHAMNANI B and SINGH S (2009) Groundwater contamination due to Bhalaswa landfill site in New Delhi. Int. J. Environ. Sci. Eng. 1 121-125.

JORSTAD LB, JANKOWSKI J and ACWORTH RI (2004) Analysis of the distribution of inorganic constituents in a landfill leachatecontaminated aquifer: Astrolabe Park, Sydney, Australia. Environ Geol. 46 263-272.

KJELDSEN P, BARLAZ MA, ROOKER, AP, BAUN A, LEDIN A and CHRISTENSEN TH (2002) Present and long-term composition of MSW landfill leachate: a review. Crit. Rev. Environ. Sci. Technol. 32 297-336. https://doi.org/10.1080/10643380290813462

KUMAR S, NIMCHUK N, KUMAR R, ZIETSMAN J, RAMANI T, SPIEGELMAN C and KENNEY M (2016) Specific model for the estimation of methane emission from municipal solid waste landfills in India. Bioresour. Technol. 216 981-987. https://doi. org/10.1016/j.biortech.2016.06.050

LI Z, FENG X, TANG S, WANG S and LI P (2005) Mercury in landfill leachate and its removal by the on-site sewage treatment plant. Diqiu Huanjing. 33 52-56.

LINDBERG SE, WALLSCHLAEGER D, PRESTBO EM, BLOOM NS, PRICE J and REINHART D (2001) Methylated mercury species in municipal waste landfill gas sampled in Florida, USA1. Atmos. Environ. 35 4011-4015. https://doi.org/10.1016/ S1352-2310(01)00176-5

LINDBERG SE and PRICE JL (1999) Airborne emissions of mercury from municipal landfill operations: a short-term measurement study in Florida. J. Air. Waste Manage. Assoc. 49 520-532. https:// doi.org/10.1080/10473289.1999.10463825

LONGE E and BALOGUN M (2010) Groundwater quality assessment near a municipal landfill, Lagos, Nigeria. Res. J. Appl. Sci. Eng. Technol. 2 39-44.

LOOSER M, PARRIAUX A and BENSIMON M (1999) Landfill underground pollution detection and characterization using inorganic traces. Water Res. 33 3609-3616. https://doi.org/10.1016/ S0043-1354(99)00062-7

MACHADO W, MOSCATELLI M, REZENDE L and LACERDA L (2002) Mercury, zinc, and copper accumulation in mangrove sediments surrounding a large landfill in southeast Brazil. Environ. Pollut. 120 455-461. https://doi.org/10.1016/S0269-7491(02)00108-2

MACHADO SL, CARVALHO MF, GOURC JP, VILAR OM and DO NASCIMENTO JC (2009) Methane generation in tropical landfills: Simplified methods and field results. Waste. Manage. 29 153-161. https://doi.org/10.1016/j.wasman.2008.02.017

MAHAPATRA DM, CHANAKYA HN and RAMACHANDRA TV (2011) Assessment of treatment capabilities of Varthur Lake, Bangalore, India. Int. J. Environ. Technol. Manage. 14 84-102.

MALEHASE T, DASO AP and OKONKWO JO (2016) Determination of mercury and its fractionation products in samples from legacy use of mercury amalgam in gold processing in Randfontein, South Africa. Emerg. Contam. 2 157-165. https://doi.org/10.1016/j. emcon.2016.07.003

MAMBA BB, RIETVELD LC and VERBERK JQJC (2008) SA drinking water standards under the microscope: drinking water. The Water Wheel 7 24-27.

MOR S, DE VISSCHER A, RAVINDRA K, DAHIY R, CHANDRA A 
and VAN CLEEMPUT O (2006) Induction of enhanced methane oxidation in compost: Temperature and moisture response. Waste Manage. 26 381-388. https://doi.org/10.1016/j.wasman.2005.11.00

NAVEEN B, MAHAPATRA DM, SITHARAM T, SIVAPULLAIAH P and RAMACHANDRA T (2017) Physico-chemical and biological characterization of urban municipal landfill leachate. Environ. Pollut. 220 1-12. https://doi.org/10.1016/j.envpol.2016.09.002

O'DELL JW, POTTER BB, LOBRING LB and MARTIN TD (1994) Determination of Mercury in Water by Cold Vapor Atomic Absorption Spectroscopy, Method 245.1. US Environmental Protection Agency, Washington, DC.

OGOLA JS, CHIMUKA L and TSHIVHASE S (2011) Management of Municipal Solid Wastes: A Case Study in Limpopo Province, South Africa. In: Kumar S (ed) Integrated Waste Management - Volume I. InTech, Hungary.

OLIVIER J, VAN NIEKERK HJ and VAN DER WALT IJ (2008) Physical and chemical characteristics of thermal springs in the Waterberg area in Limpopo Province, South Africa. Water SA 34 $163-174$.

OLIVIER J, VENTER JS and JONKER CZ (2011) Thermal and chemical characteristics of hot water springs in the northern part of the Limpopo Province, South Africa. Water SA 37 427-436.

OOSTHUIZEN M, JOHN J and SOMERSET V (2010) Mercury exposure in a low-income community in South Africa. S. Afr. Med. J. $100366-371$.

ØYGARD JK, MÅGE A and GJENGEDAL E (2004) Estimation of the mass-balance of selected metals in four sanitary landfills in Western Norway, with emphasis on the heavy metal content of the deposited waste and the leachate. Water Res. 38 2851-2858. https:// doi.org/10.1016/j.watres.2004.03.036

PACYNA EG, PACYNA JM, STEENHUISEN F and WILSON S (2006) Global anthropogenic mercury emission inventory for 2000. Atmos. Environ. 40 4048-4063. https://doi.org/10.1016/j. atmosenv.2006.03.041

PACYNA JM, PACYNA EG, STEENHUISEN F and WILSON S (2003) Mapping 1995 global anthropogenic emissions of mercury. Atmos. Environ. 37 109-117. https://doi.org/10.1016/S1352-2310(03)00239-5

RAMAIAH B, RAMANA G and DATTA M (2017) Mechanical characterization of municipal solid waste from two waste dumps at Delhi, India. Waste Manage. https://doi.org/10.1016/j. wasman.2017.05.055

RAPTI-CAPUTO D and VACCARO C (2006) Geochemical evidences of landfill leachate in groundwater. Eng. Geol. 85 111-121. https:// doi.org/10.1016/j.enggeo.2005.09.032

RENOU S, GIVAUDAN J, POULAIN S, DIRASSOUYAN F and MOULIN P (2008) Landfill leachate treatment: review and opportunity. J. Hazardous Mater. 150 468-493. https://doi. org/10.1016/j.jhazmat.2007.09.077

SAARELA J (2003) Pilot investigations of surface parts of three closed landfills and factors affecting them. Environ. Monit. Assess. 84 183-192. https://doi.org/10.1023/A:1022859718865

SAMADDER SR, PRABHAKAR R, KHAN D, KISHAN D and CHAUHAN M (2017) Analysis of the contaminants released from municipal solid waste landfill site: A case study. Sci. Total Environ. 580 593-601. https://doi.org/10.1016/j.scitotenv.2016.12.003

SCHOEMAN JJ, STEYN A, SLABBERT J and VENTER E (2003) Treatment of landfill leachate from hazardous and municipal solid waste. WRC Report No. 2003/01/02. Water Research Commission, Pretoria.

SIBIYA IV, OLUKUNLE OI and OKONKWO OJ (2017) Seasonal variations and the influence of geomembrane liners on the levels of PBDEs in landfill leachates, sediment and groundwater in Gauteng Province, South Africa. Emerg. Contam. 3 76-84.

SINGH UK, KUMAR M, CHAUHAN R, JHA PK, RAMANATHAN A and SUBRAMANIAN V (2008) Assessment of the impact of landfill on groundwater quality: a case study of the Pirana site in western India. Environ Monit. Assess. 141 309-321. https://doi. org/10.1007/s10661-007-9897-6

SLACK R, GRONOW J and VOULVOULIS N (2004) Hazardous components of household waste. Crit. Rev. Environ. Sci. Technol. 34 419-445. https://doi.org/10.1080/10643380490443272

TANG QH, DING ZH, HUANG RH, WANG HJ and WANG WH (2003) Mercury pollution of water system in landfill site. Urban Environ. Urban Ecol. 16 15-17.

TSHIBALO R (2017) Assessment of municipal solid waste leachate pollution on soil and groundwater system at Onderstepoort landfill site in Pretoria. http://hdl.handle.net/10500/22639

USEPA (United States Environmental Protection Agency) (1997) Mercury study report to Congress. Office of Air Quality Planning and Standards and Office of Research and Development. URL: http://www.epa.gov/ttnatw01/112nmerc/ volume1.pdf (Accessed 2012). Documentation for the final 2005 Point Source National Emission inventory. USEPA, Washington DC.

USEPA (United States Environmental Protection Agency) (2007). Method 7471B (SW-846): Mercury in Solid or Semisolid Wastes (Manual Cold-Vapor Technique). USEPA, Washington DC.

VADILLO F, CARRASCO B, ANDREO A, and GARCIA DE TORRES C (1999) Bosch. Environ. Geol. 37 326-332.

WILLIAMS CR, LEANER JJ, SOMERSET VS and NEL JM (2011) Mercury concentrations at a historically mercury-contaminated site in KwaZulu-Natal (South Africa). Environ. Sci. Pollut. Res. 18 1079-1089. https://doi.org/10.1007/s11356-011-0458-8

XU J, KREJA BD, BIESTER H, LAGERKVIST A, KUMPIENE J (2014) Influence of particle size distribution, organic carbon, $\mathrm{pH}$, and chlorides on washing of mercury contaminated soil. Chemosphere. 109 99-105. https://doi.org/10.1016/j.chemosphere.2014.02.058

ZHANG L, ZHUO Y, CHEN L, XU X and CHEN C (2008) Mercury emissions from six coal-fired power plants in China. Fuel. Process Technol. 89 1033-1040. https://doi.org/10.1016/j.fuproc.2008.04.002 